\title{
Documentation of Model Input and Output Values for Simulation of Pumping Effects in Paradise Valley, A Basin Tributary to the Humboldt River, Humboldt County, Nevada
}

\author{
By Anne E. Carey and David E. Prudic
}

Supplement to U.S. Geological Survey Professional Paper 1409-F

U.S. GEOLOGICAL SURVEY

Open-File Report 92-491

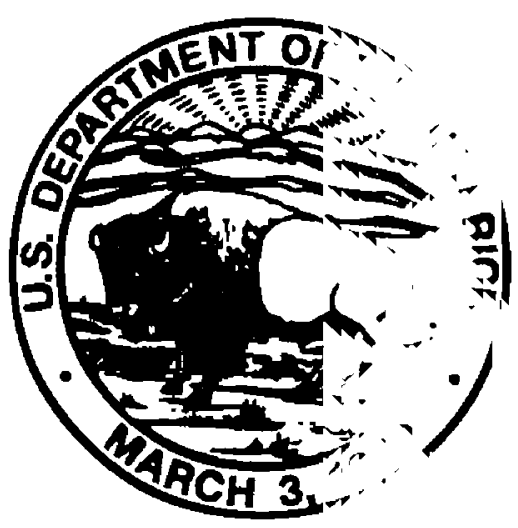

Carson City, N'evada 1996 


\section{Documentation of Model Input and Output Values for Simulation of Pumping Effects in Paradise Valley, A Basin Tributary to the Humboldt River, Humboldt County, Nevada}

\section{By Anne E. Carey and David E. Prudic ABSTRACT}

Documentation is provided of model input and sample output used in a previous report for analysis of ground-water flow and simulated pumping scenarios in Paradise Valley, Humboldt County, Nevada. Documentation includes files containing input values and listings of sample output. The files, in American International Standard Code for Information Interchange (ASCII) or binary format, are compressed and put on a 3-1/2inch diskette. The decompressed files require approximately 8.4 megabytes of disk space on an International Business Machine (IBM)-compatible microcomputer using the MicroSoft Disk Operating System (MS-DOS) operating system version 5.0 or greater.

\section{INTRODUCTION}

Paradise Valley, Nev., is a narrow valley approximately 40 miles long that extends north-northeastward from the Humboldt River near Winnemucca. Groundwater flow and response to hypothetical development of ground water in this basin were simulated as part of the U.S. Geological Survey Great Basin Regional Aquifer-System Analysis (RASA) project (Harrill and others, 1983). A three-layer digital model was developed for Paradise Valley using a computer program written by McDonald and Harbaugh (1988). Results of the model are given by Prudic and Herman (1995).

Although the report by Prudic and Herman (1995) summarizes the data input to the model, a detailed description of grid location, a listing of model input values, and sample output have not been published previously. The purpose of this report, which is a supplement to the report by Pridic and Herman (1996), is to provide more detailed documentation of the model.

\section{MODEL GRID}

The basin-fill aquifer of Paradise Valley was represented by a three-layer finite-difference model of 33 columns and 89 rows, with nodes 2,500 feet apart at the centers of the cells. The model has 1,691 active cells in the top layer (layer 1), 1,440 active cells in the middle layer (layer 2), and 1,195 active cells in the bottom layer (layer 3). The model is surrounded by inactive cells through which there is no flow. The model grid is oriented along the major axis of the valley and is rotated approximately 13 degrees east of a north-south line. Latitude and longitude of the four ccrners of the grid (beginning at the origin of the grid at the northwesternmost corner and continuing in a c'sckwise direction) are as follows.

\begin{tabular}{lll}
\hline Corner & $\begin{array}{c}\text { North } \\
\text { latltude }\end{array}$ & $\begin{array}{c}\text { West } \\
\text { lo7gltude }\end{array}$ \\
\hline Northwest & $41^{\circ} 37^{\prime} 07^{\prime \prime}$ & $117^{\circ} 37^{\prime} 51^{\prime \prime}$ \\
Northeast & $41^{\circ} 35^{\prime} 01^{\prime \prime}$ & $117^{\circ} 19^{\prime} 58^{\prime \prime}$ \\
Southeast & $40^{\circ} 58^{\prime} 49^{\prime \prime}$ & $117^{\circ} 27^{\prime} 32^{\prime \prime}$ \\
Southwest & $41^{\circ} 00^{\prime} 54^{\prime \prime}$ & $117^{\circ} 45^{\prime} 16^{\prime \prime}$ \\
\hline
\end{tabular}

Recharge to the basin-fill aquifer is primarily from streams that become ephemeral during summer and fall. A computer program (Prudic, 1989), designed specifically for use with the ground-water flow model of McDonald and Harbaugh (1988), was used to route variable streamflows through the modeled area and to compute leakage to and from the streams. 
The program divides streams into reaches and segments. A reach is the part of a stream that corresponds to a model cell; segments are groups of reaches in which no tributary flow from other streams is added and from which no water is diverted to ditches or canals. In the model for Paradise Valley, 274 reaches and 27 segments were used to simulate varying leakage to and from streams. Included with the stream package is a section of the Humboldt River used as the southern boundary of the modeled area.

The model simulated predevelopment and pumping conditions, with a steady-state simulation for predevelopment conditions and transient simulations for three pumping periods (1948-68, 1969-78, 1979-82).

The pumping period 1948 to 1968 was divided into four stress periods: $1948-53,1954-58,1959-65$, and 1966-68. The period from $1969-78$ was divided into 10 stress periods, each of 1-year duration. The period 1979-82 was divided into 16 stress periods, each of 3month duration.

\section{INPUT AND OUTPUT FILES}

Original input and output files for the Paradise Valley model were developed on a Prime computer, transferred to microcomputer, and compressed so they would fit on a single diskette. The compressed files were collected into two self-extracting files, or libraries, named INPUT.EXE and OUTPUT.EXE. A diskette (included in this report) contains a copy of this text (README.TXT) and the compressed files. The 3-1/2inch diskette has a capacity of 1.2 megabytes. Files compressed on the diskette were created on an IBM compatible microcomputer using MS-DOS version 5.0. The file compression was performed using LHarc version $1.13 \mathrm{c}$ (copyright Haruyasu Yoshizaki). The decompressed files require approximately 8.4 megabytes of disk space. To decompress the files, copy the self-extracting libraries (INPUT.EXE and OUTPUT.EXE) to the desired directory on a hard disk. Type INPUT (or OUTPUT) and press the enter key. Computer instructions contained within INPUT.EXE and OUTPUT.EXE will decompress the files into that directory. Decompression of INPUT.EXE creates 54 model-input files (table 1); decompression of OUTPUT.EXE creates 4 model-output files (table 2). The decompressed files are identical to the original input and output files and are in the American International Standard Code for Information Intercl ange (ASCII) format.

Data contained in the files are in units of feet and seconds, except as noted. The model program, written in Fortran 77, can be used on a variety of computers; the input files might require reorganization depending on the specific computer and compiler used, and the computed output might differ slightly from that presented here.

\section{REFERENCES CITED}

Harrill, J.R., Welch, A.H., Prudic, D.E., Thomas, J.M., Carman, R.L., Plume, R.W., Gates, J.S., and Mason, J.L., 1983, Aquifer systems in the Great $E$ asin region of Nevada, Utah, and adjacent states--A study plan: U.S. Geological Survey Open-File Report 82-445, 49 p.

Prudic, D.E., 1989, Documentation of a computer program to simulate stream-aquifer relations v'sing a modular, finite-difference, ground-water flow model: U.S. Geological Survey Open-File Report 88-729, 113 p.

Prudic, D.E., and Herman, M.E., 1996, Ground-water hydrology and simulated effects of $d$ vvelopment in Paradise Valley, a basin tributary to the Humboldt River in Humboldt County, Nevada: U.S. Geological Survey Professional Paper 1409-F, 92 p.

McDonald, M.G., and Harbaugh, A.W., 1988, A modular three-dimensional finite-difference g-ound-water flow model: U.S. Geological Survey Techriques of WaterResources Investigations, Book 6, Cliapter A1, 586 p. 
Table 1. Model-input files, Fortran units, sizes, maximum record lengths, and descriptions

\begin{tabular}{|c|c|c|c|c|}
\hline File & $\begin{array}{l}\text { Fortran } \\
\text { unit }\end{array}$ & $\begin{array}{c}\text { Size } \\
\text { (bytes) }\end{array}$ & $\begin{array}{l}\text { Maximum } \\
\text { record length } \\
\text { (characters) }\end{array}$ & Description \\
\hline BAS.DTA & 5 & 455 & 72 & Steady-state model, basic information \\
\hline BCF.DTA & 7 & 298 & 39 & Steady-state model, block centered flow information \\
\hline BOT1.DTA & 30 & 21,271 & 76 & Altitude at bottom of layer 1 \\
\hline ELEV.DTA & 54 & 18,156 & 78 & Land-surface altitude \\
\hline EVT.DTA & 11 & 139 & 46 & Steady-state model, evapotranspiration information \\
\hline HYCOND1.DTA & 29 & 6,052 & 72 & Hydraulic conductivity, layer 1 \\
\hline IBOUND1.DTA & 42 & 6,052 & 72 & Boundary, layer 1 \\
\hline IBOUND2.DTA & 44 & 6,052 & 72 & Boundary, layer 2 \\
\hline IBOUND3.DTA & 46 & 6,052 & 72 & Boundary, layer 3 \\
\hline OC.DTA & 17 & 210 & 46 & Steady-state model, output control information \\
\hline RCH.DTA & 14 & 24,344 & 86 & Steady-state model, recharge package information \\
\hline SHEAD1.DTA & 48 & 12,104 & 78 & Steady-state model, starting heads, layer 1 \\
\hline SHEAD2.DTA & 50 & 12,104 & 78 & Steady-state model, starting heads, layer 2 \\
\hline SHEAD3.DTA & 52 & 12,104 & 78 & Steady-state model, starting heads, layer 3 \\
\hline SIP.DTA & 15 & 74 & 56 & Steady-state model, Strongly Implicit Procedure information \\
\hline STR.DTA & 18 & 21,536 & 86 & Steady-state model, streamflow data \\
\hline SY1.DTA & 31 & 9,168 & 85 & Primary storage coefficient, layer 1 \\
\hline THICK2.DTA & 33 & 21,271 & 76 & Primary storage coefficient, layer 2 \\
\hline THICK3.DTA & 37 & 21,271 & 76 & Primary storage coefficient, layer 3 \\
\hline TRANS2.DTA & 34 & 30,260 & 76 & Transmissivity, layer 2 \\
\hline TRANS3.DTA & 40 & 30,260 & 76 & Transmissivity, layer 3 \\
\hline VC12.DTA & 32 & 30,260 & 76 & Vertical conductivity between layers 1 and 2 \\
\hline VC23.DTA & 36 & 30,260 & 76 & Vertical conductivity between layers 2 and 3 \\
\hline T48HEAD1.DTA & 48 & 12,104 & 78 & Transient model, initial heads, layer 1 (1948-68) \\
\hline T48HEAD2.DTA & 50 & 12,104 & 78 & Transient model, initial heads, layer 2 (1948-68) \\
\hline T48HEAD3.DTA & 52 & 12,104 & 78 & Transient model, initial heads, layer 3 (1948-68) \\
\hline T69HEAD1.DTA & 48 & 21,093 & 83 & Transient model, initial heads, layer 1 (1969-78) \\
\hline T69HEAD2.DTA & 50 & 21,093 & 83 & Transient model, initial heads, layer 2 (1969-78) \\
\hline T69HEAD3.DTA & 52 & 21,093 & 83 & Transient model, initial heads, layer 3 (1969-78) \\
\hline T78HEAD1.DTA & 48 & 21,093 & 83 & Transient model, initial heads, layer 1 (1979-82) \\
\hline T78HEAD2.DTA & 50 & 21,093 & 83 & Transient model, initial heads, layer $2(1979-82)$ \\
\hline T78HEAD3.DTA & 52 & 21,093 & 83 & Transient model, initial heads, layer 3 (1979-82) \\
\hline T69HEAD.OUT & 56 & 141,552 & -- & $\begin{array}{l}\text { Transient model, calculated heads, end of } 1969-78 \text { (binary file). File used to } \\
\text { produce heads for 1979-82 pumping periods }\end{array}$ \\
\hline TBAS48.DTA & 5 & 547 & 71 & Transient model, basic information (1948-68) \\
\hline TBAS69.DTA & 5 & 729 & 74 & Transient model, basic information (1969-78) \\
\hline TBAS79.DTA & 5 & 940 & 74 & Transient model, basic information (1979-82) \\
\hline TBCF.DTA & 7 & 391 & 39 & Transient model, block-centered flow information \\
\hline TEVT48.DTA & 11 & 265 & 46 & Transient model, evapotranspiration data (1948-68) \\
\hline TEVT69.DTA & 11 & 517 & 46 & Transient model, evapotranspiration data (1969-78) \\
\hline TEVT79.DTA & 11 & 1,099 & 46 & Transient model, evapotranspiration data (1979-82) \\
\hline TOC48.DTA & 17 & 2,115 & 80 & Transient model, output control information (1948-68) \\
\hline TOC69.DTA & 17 & 3,125 & 82 & Transient model, output control information (1969-78) \\
\hline TOC79.DTA & 17 & 5,101 & 90 & Transient model, output control information (1979-82) \\
\hline
\end{tabular}


Table 1. Model-input files, Fortran units, sizes, maximum record lengths, and descriptions --Continued

\begin{tabular}{lcrrl}
\hline \multicolumn{1}{c}{ Flle } & $\begin{array}{c}\text { Fortran } \\
\text { unit }\end{array}$ & $\begin{array}{c}\text { Size } \\
\text { (byte8) }\end{array}$ & $\begin{array}{c}\text { Maximum } \\
\text { record length } \\
\text { (characters) }\end{array}$ & \multicolumn{1}{c}{ Description } \\
\hline TRCH48.DTA & 14 & 262 & 57 & Transient model, recharge data (1948-68) \\
TRCH69.DTA & 14 & 804 & 63 & Transient model, recharge data (1969-78) \\
TRCH79.DTA & 14 & 1,374 & 72 & Transient model, recharge data (1979-82) \\
TRECHARG.DTA & 16 & 387,328 & 86 & Transient model, recharge location array \\
TSIP.DTA & 15 & 74 & 56 & Transient model, Strongly Implicit Procedure information \\
TSTR48.DTA & 18 & 87,228 & 86 & Transient model, streamflow data (1948-68) \\
TSTR69.DTA & 18 & 215,792 & 86 & Transient model, streamflow data (1969-78) \\
TSTR79.DTA & 18 & 343,026 & 86 & Transient model, streamflow data (1979-82) \\
TWELL48.DTA & 8 & 11,620 & 46 & Transient model, well data (1948-68) \\
TWELL69.DTA & 8 & 56,640 & 66 & Transient model, well data (1969-78) \\
TWELL79.DTA & 8 & 88,748 & 84 & Transient model, well data (1979-82) \\
& Total & $1,831,720$ bytes & & \\
\hline
\end{tabular}

Table 2. Model-output files, Fortran units, sizes, and descriptions

\begin{tabular}{lccl}
\hline \multicolumn{1}{c}{ File } & Fortran unlt & Size (bytes) & \multicolumn{1}{c}{ Description } \\
\hline PVRUN.LST & 6 & 675,365 & Output for steady-state simulation \\
PVT48RUN.LST & 6 & $1,294,018$ & Output for transient simulation (1948-68) \\
PVT69RUN.LST & 6 & $1,952,085$ & Output for transient simulation (1969-78) \\
PVT79RUN.LST & 6 & $2,687,047$ & Output for transient simulation (1979-82) \\
& \multicolumn{2}{c}{ Total } & $6,608,515$ bytes \\
\hline
\end{tabular}

